\title{
The Analysis of Form and Meaning of Written Language in Social Media
}

\author{
Suranto* \\ English Language Education \\ STKIP PGRI Lampung \\ Lampung, Indonesia \\ surantoenglish@gmail.com
}

\author{
Septa Aryanika \\ English Language Education \\ UIN Raden Intan \\ Lampung, Indonesia \\ Septaaryanika@radenintan.ac.id
}

\begin{abstract}
The objective of this research was to examine the form and meaning of written language used in social media as a means to communicate between users of social media. It was a qualitative research with descriptive qualitative method. The data were collected through observation and document study. The data analysis and interpretation indicates that there are five forms of discourse used by the Facebookers they are descriptive form, narrative form, exposition form, argumentative form, and persuasive form. There are also six styles of meaning they are denotative, connotative, idiom, synonym, antonym, and ambiguity. The finding indicated that the user of Facebook tended to use those form and meaning of written language to express their feeling.
\end{abstract}

Keywords-form, meaning, and social media

\section{INTRODUCTION}

Cyberspace is now a new world for some people, the presence of it cannot be avoided. It was American Defense Department in the mid of 1970 s first developed to connect people and data among them. After 1990s it began to develop and influence many people around the world.

Nowadays, internet is very easy to access, it was different from the condition several years ago where people can only access internet through certain places like internet café and internet shop. But now everybody can access internet from their home even from their hand by using smart phones.

Internet grows rapidly after becoming means of mass communication, in this case social media become the main means of communication for all people starting from students, businessman, actor/actress, official, politicians of course with their own purposes.Social media has become a medium for communication between users of social media and is done online.(Kholmogorova $\mathrm{AB}$ 2016) in her research about internet communication stated that adult and adolescence prefer to do an interface communication through social media. Social media enable people to interact with each other without being limited by space and time. Through social media everyone can communicate using text, picture, voice, and even video.

Another research by Mukhlishin about language style in Facebook communication special for male actor in Malang City and the result showed that male actors in Malang city tended to use personification language style and simile (Mukhlishin, 2016) in Mukhlishin's research the focus on how language style used to communicate in Facebook specially among the actor and the relationship with this research was the form and meaning in personification language style used in those communication.

It was different from Mukhlishin another research done by Lilimiwirdi focus on the use of language for teenagers in making interaction through Facebook and the result showed that their language was affected by computer language in English taken through collection, adjustment and adoption. (Lilimiwirdi, 2016)

The significance of this research was to know the form and meaning used by the Facebookers in expressing their thinking through social media.

\section{A. Written Communication}

The way of communication through social media used written communication. Written communication is the way to communicate using written media without direct talks, using language that is concise, clear and understandable to the recipient

Written communication can be in the form of correspondence, short message services, and of course through social media. This is the basis of this research study on how the written communication of social media users as a tool for social interaction, because the most important function of language is as a communication and interaction tool (Sobur, 2006). Communication without language is something that is impossible. The communication process can be described as the successful delivery of messages from a person or party to another person or another party. So in this context, communication also includes "transmission" of knowledge about a thing. However, the process of further communication is not just the delivery of information, but the process of interaction of knowledge and truth between the first party and the second party and so on. In brief, the role and function of language is very important in communicating (Sobur, 2006).

\section{B. Form}

In written communication there is a form of language that must be written in the form of words and every words have their own meaning, related to those Dale Mathers in Meaning and purposes in analytical Psychology stated that

As we build meaning in sharing this text, we share naming percepts. This allows new meaning and purpose to emerge. When we play with meaning, change occurs in the collective and ourselves. New questions arise: for instance, what is the purpose of meaning? (Dale Mathers, 2004).

So the form of written language used to communicate in Facebook will have different meaning depends on the perception of the readers.

In this research the researcher tried to examine the form and meaning of written language used in social media as a means to communicate among the users. Based on those 
background it is interesting to discuss about the language used in social media and the research questions are:

- How is the form of written language used to communicate in social media?

- How is the meaning of written language used to communicate in social media?

By using the theory of discourse forms, researchers can examine more deeply about the form of language used in social media. As stated by (Marwoto et al, 1987). All forms of oral and written exposures that are characterized as being a means of conveying information or a whole mind are called discourse. Theoretically the discourse is distinguished as follows (Marwoto, 1987).

- Description, from the word to describe, which means to describe, exhort, describe or illustrate. Discourse description is a discourse used to arouse impressions about someone, a place, a view and so forth.

- Narration, this form literally means a story. The form of narration aims to tell a story. Narration can be limited as a form of discourse whose main target is an act that is woven and arranged into an event that occurs in a unified time. Narration can also be formulated as a form of discourse that seeks to describe as clearly as possible to the reader an event that has occurred.

- Expositionthis discourse that gives, peels or describes something for the sake of delivery information and without any compulsion or coercion. Forms of exposition are commonly used to present knowledge, definitions, understandings, steps of an activity, methods, ways, and the process of something happening.

- Argumentation, from the word to argue which means to prove or convey a reason. The form of argumentation seeks to influence the attitudes and opinions of others, so that they believe and ultimately act according to what the writer or speaker wants through arguments to convince the reader that what is being said is true, the author includes evidence, examples, and various reasons that are difficult to refute.

- $\quad$ Persuasion, from the verb to persuade which means to persuade, or suggest. The form of persuasion is a continuation or development of the form of argumentation. Persuasion first presents ideas with reason, evidence, or example to convince the reader. Then followed by solicitation, persuasion, flattery, appeal, or advice to the reader.

\section{Meaning}

To elaborate more about the study, the researcher also uses the theory of semantic studies. There are many theories which have been developed by philosophers and linguists around the concepts of meaning and semantic studies. Basically philosophers and linguists question the meaning in the form of the relationship between language (speech), mind, and reality in nature. Thus was born the theory of meaning which revolves around the relationship between speech, thought, and reality in the real world. From these various theories emerged various kinds and relations of meaning as follows:

- The first variety of meaning is denotative meaning, in a general definition this meaning is considered as a central factor in language communication. Denotative meaning is conceptual meaning, original meaning or actual meaning possessed by a lexeme.

- The second variety of meaning is connotative meaning, it is the communicative value of a phrase according to what is referred to, exceeds the purely conceptual content. The boundary between conceptual meanings and connotative meaning is also a vague meaning, but what is easily understood is the difference between these two meanings such as the difference between 'language' and 'real world'. The meaning of connotation is the meaning whose use is intended to give 'sense value' to a word contained in the message.

- The third variety of meaning is idiomatic meaning, which means are units of language can be in the form of words, phrases, and sentences. These various language units have elements of meaning that cannot be guessed lexically and grammatically. The meaning of this idiom is no longer related to the lexical or grammatical meaning, then these idiom forms have their own lexical units whose meaning is also the lexical meaning of the unit.

- The fourth variety of meaning is synonymy meaning, synonymy shows the existence of a relationship of the same meaning between two words which are two directions. The two words that are synonymous are not one hundred percent similar in meaning but only more of less the same. This is because the form of the words is not absolutely the same so the meaning is also slightly different.

- The fifth variety of meaning is antonymic meaning, the antonymic semantically is an expression it can be a word, phrase, and sentence whose meaning is considered to be the opposite of the meaning of other expressions. The meaning of antonymic can be said to be an opposition of meanings from two different forms of expression.

- The sixth variety of meaning is ambiguity meaning, this variety of meaning is a word that has double meaning or ambiguous meaning. The double meaning in ambiguity comes from the larger grammatical units, phrases and sentences or more than just words (Verhaar in Chaer. 2009).

A study conducted by (Arini. 2013) in her thesis tried to analyze the form, meaning, and function of social media written language as a communication and interaction tool on the internet from Airlangga University showed the following results and findings: based on data obtained by social media messages can be categorized into five forms of discourse. In addition, five different meanings and relationship of meanings were found in messages published through social media. There are also seven language functions that appear in communicating through social media. The interaction function is one of the main functions of using social media as 
a communication tool. The written language found on social media shows the diversity of its users. Communication using social media has become one of the main choices for the community.

A study on improving students' ability to understand the structure of discourse through critical discourse analysis methods based on social media literacy conducted by (Cecep Dudung Julianto. 2019) provides an illustration of the need for critical discourse analysis on the meaning and text messages in social media so as not to cause 'communication crisis'

Referring to the research, this research seeks to enrich the realm of discourse analysis based on the written language used by social media users in communicating and interacting specifically on Facebook social media. Researchers deliberately limit it to only one social media Facebook, because social media has a very large user in Indonesia and allows for interaction.

\section{METHOD}

This research is a descriptive research (descriptive research) which is the most basic form of research aimed at describing the phenomena that exist, both natural and human engineering. This study examined the forms, activities, characteristics, changes, relationships, similarities and differences with other phenomena (Gay and Mills, 2012).

Related to this research, the data source is the status of Facebook users, the status will be the object to be observed and analyzed. Researchers observed and analyzed the status of Facebook users in various situations and then grouped the status into various forms of discourse and discourse meaning.

\section{RESULT AND DISCUSSION}

The results and discussion of this study are divided into two major parts: the analysis of form of written language and analysis of meaning in written language obtained from Facebook status.

\section{A.The Analysis of Form of Written Language on Facebook Status}

The form in this study refers to the series of words and sentences used in conveying one's status through his Facebook account. Messages published through social media take various forms. In the research in order to be able to examine completely and surely the various forms of social media language, the researchers used the theory of discourse forms. With the theory of discourse analysis and discourse forms researchers can examine more deeply about the form of language used on social media.

Ridho Kholid Muhammad's Facebook status on June 20, 2017 at 15.51 (Ridho Kholid Muhammad is a civil servant lecturer at UIN Raden Intan Bandar Lampung studying strata 3 at Jakarta State University) "Islam is still understood in 'fiqh oriented". This paradigm views worship only in black and white ". The Facebook status form shows a description of the understanding of Islam. The author tried to describe the understanding of Muslims who still focus on the understanding of fiqh, is still partial, even though Islam must be understood in full. From the discourse analysis it can be concluded that the author felt anxiety about religious life, especially in Indonesia if Islam is only understood partially because it will cause division. At least that's the picture captured by the author about the condition of understanding Muslims in Indonesia

Ridho Kholid Muhammad's Facebook status on May 28 2017 at 05.51 (Ridho Kholid Muhammad is a civil servant lecturer at UIN Raden Intan Bandar Lampung studying strata 3 at Jakarta State University) "I'm a lecturer. I'm a master. I graduated quickly with a very good GPA. What for took a long time after school is just a condition "the important thing is to pass the exam". I don't feel ashamed to be a lecturer. Precisely proud. I don't read books. Hey, you guys don't laugh yet. What for Larry Page and Sergey Brin founded Google if there was no benefit. I can read a synopsis of the book via the internet. Besides, Google provides many links that make it easy for me to find out the contents of the book without having to buy and read every page. Reading is tiring! I don't need to write either. By looking at the Google site, I can easily copy and paste what I want. My Facebook is filled with selfies that often have nothing to do with the profession. Do not ask why. That is my hobby. And again, this is my Facebook account. You don't need to manage even talking to what I'm doing. My activities 'arisan'. In addition to strengthening friendship, social gathering is the same as saving. I mostly go to the Mall just to just look at the latest second quality goods. Understandably, my salary is not enough to buy branded goods. Oh yeah, as well as promotions, you guys can look at my Instagram account. I tried a small business. I sell household appliances. I guarantee, the price is cheap. Nothing important is halal, anyway. Who knows, I can immediately have a car. The vehicle is important. And, the parameters of a person's success can be seen from what he already has. One more thing, pray for me to be able to pursue further education. Strata 3. I request information if there is a cheap and fast campus.

The narration delivered in the Facebook status tells about the life of a lecturer that is far from ideal, but that is what happened in the real world. The story above if we further analyze is not the real life of the writer, it could be that the narration above is a satire for other lecturers who do not have to be like that. There is a hidden message from the narration above by presenting the character "me" which can be interpreted by people who are reading the status.

Heri Nurdianto's Facebook status on May 9, 2017 at 06.36 (Heri Nurdianto is a lecturer at the Dharma Wacana Metro and is currently pursuing his doctoral degree at Yogyakarta State University) "Khairunnas' anfauhum linnas - the best of humans is someone who gave benefits to others" (Rasulullah SAW). I just realized that this is the key to everything called true career success. "Be a man of value, not a man of success," Einstein said. Giving more value to everything, including our behavior, is not easy. But those who succeed in doing so, they are the ones who get the best chance, so it is called as those who succeed, the best one. Even in the business world, there is a science that teaches how to create "value" in every business commodity. So be useful first, before getting benefits. Because when we present as a solution, that's where our existence is truly felt by others. 
This status explained the definition of being the best human according to Rasulullah SAW provides an explanation of how it should be a human being in this world, to get the benefits then we must give benefits first. Steps that must be taken to become the best human being. This form of status is a form of definition exposition. Where it explained the stages that must be passed if someone wants to obtain benefits, they must give benefits.

The following is Rudi Haryono's Facebook status on June 23, 2017 at 22.57 (Rudi Haryono is a strata 3 student at Atmajaya University Jakarta) "Apologizing is a reflection of human nature that does not have perfection and free from sin and mistakes. So it is true, that forgiveness is the abolition of human arrogance that is not appropriate for arrogance, whatever its parameters. Indeed, the context of forgiving others is based on the manifestation of one of Allah's most forgiving qualities. Congratulations on welcoming Iedul Fitri $1438 \mathrm{H}$. We apologize for being born with a sincere and clear conscience. Forgiving and apologizing is what truly calms the soul and taste. May Indonesia peace, stop hatred. In this status there are several arguments to forgive each other, an invitation that the reader does not act arrogant because there is nothing that should be arrogant by humans and ultimately influence the reader to do what is said in that status. This form of status is included in the argumentation.

Endang Taryono's Facebook status on May 13, 2017 at 19.05 (Endang Taryono is a staff member at the Ministry of Research and Higher Education) Muhasabah / Selfintrospection ... PREJUDICED.

"A small child is holding two apples in his hand. Then her mother came closer, smiling and asking "Honey ... can you give me one?" The child looks at his mother for a few seconds, then quickly bites his two apples, alternately ...? The mother tried to hide her disappointment, her smile immediately faded from her face ...? Until then the child handed one of the apples he had bitten earlier to his mother. With joy and cheerful smile the child said: This is for Mother, because this apple is MORE SWEET. Then the atmosphere is quiet for a moment ...? Apparently the child wants to give the best for his mother ...? So that the child makes sure which is sweeter between the two apples he has? Before he gave it to his mother. No words were spoken from her mother's lips, except for her smile and teary eyes ...? Don't you feel the tears flowing too? Therefore, don't be too quick to prejudice Who are you? No matter how your experience \& knowledge? Don't rush to judge someone, whoever is he? Therefore: Be patient ... and wait for the response ... and understand the meaning? Do not rush to judge, so that you will not be easily judged. Give everyone a chance to give an explanation ...? Even though it's his own way ...? So, still be a patient \& wise person to judge others ....? CAUSE OFTEN: we don't really understand what people mean ... ..........? because ... We often see things, only with our glasses? However: If we learn and want to be patient ... calm .... and want to understand with their glasses .......? Then everything will all be more beautiful. Therefore, let us always be kind to our friends, and anyone we meet? Hopefully thus, Allah SWT always bestows His mercy and pleasure on ourselves and our families! Amen YRA! ".
Even though it is presented in narrative form, by giving a case example, the status form above is a form of persuasion because we find the phrase "don't get prejudiced quickly" and at the end we also find an invitation in the form of "let's always be kind ..."

\section{B. The Analysis of Meaning of Written Language on} Facebook Status

In this study the meaning is emphasized on the meaning or purpose of the message contained and used by social media users with other users. A message published through social media certainly represents the intentions and feelings of the author. The meaning contained in each message can be implied clearly or not, depending on the message reader. Every meaning of messages published through social media has an influence on readers or other social media users who come from various backgrounds. Misinterpreted messages can certainly lead to misunderstanding of the reader. The function of social media as a medium of interaction makes a simple message can be so meaningful because the message allows it to be responded to or commented on by many people.

Ridwan Sururi Ibnu Ghozin's Facebook status on June 28, 2017 at 18.49 (Ridwan Sururi Ibnu Ghozin is a religious teacher and also a scoutmaster at a Tsanawiyah Madrasah in East Lampung) "Wetenge Konslet ... Subhanallah "in that status there is the word" short circuit "this real meaning of this word is the termination of the electric current because the wire which contains positive and negative currents touch, causing a short circuit; so the word short circuit is related to electric current, but in the above status it is used with the word 'wetenge' in Javanese which means stomach. It is impossible for the stomach to have an electric current and a short circuit occurs, so the word short circuit is a connotative meaning which can be interpreted as 'stomach ache'. Why does the author not use the word pain to indicate the condition of his stomach because using the word short circuit will give a higher value of pain, it shows that his stomach really hurts.

Rizta izzi Vandezta's Facebook status on June 28, 2017 at 08.47 (Rizta Izzi Vandezta is a teacher at a vocational school in East Lampung) "When family gatherings are blocked from making money ... Rasane nano nano" on that status the author uses the term "nano -nano "which is the brand name of a candy and is well known by the public. In the phrase above there is the word nano nano which lexically means a prefix in the metric system which means billion. In this status the author does not intend to associate with a billionth of size, but rather refers to the taste of the candy which consists of sweet, sour, salty. So the phrase nano nano is an idiom that is separated from its lexical meaning which means various things.

Fakhrudin's Facebook status on April 12, 2017 at 10:24 (Fakhrudin is a lecturer at a Private University in Metro City) Realize life is short, there must be a time to finish. Do not be fooled by young age, because the condition of death does not have to be old. Don't be deceived by a healthy body, because the condition of death does not have to hurt. Continue to do good, say good, give good advice, even though not many people understand you. "From the data on Facebook status 
can be found various antonyms such as the words" live "and" die "" young "," old "," healthy ", "Sick" and also found various synonyms namely "body" and "body".

Udin Wardoyo's Facebook status on June 1, 2017 at 09.06 (Udin Wardoyo is a self employed living in Cilacap, Central Java) "Pancasila, after the reformation of 98, as avoided in many aspects. In the end, PancaSila was very related with the New Order. so it can be justified if the PMP is then replaced by Civics, Penataran P4 missing, BP7 disbanded. Fortunately in the flag ceremony is still read. "From that status there is an ambiguous phrase that is the phrase" fortunately in the flag ceremony is still read "the sentence can mean" flag is still read "or what is still being read in the ceremony? This can lead to double or unclear meaning. To clarify the meaning of the writer should be able to add a comma after the word flag or "fortunately in the Pancasila flag ceremony is still read.

From the several Facebook statuses that researchers observed can be grouped in the following five forms: first is the form of status description in this form Ridho Kholid Muhammad account holder illustrates the understanding of Islamic teachings that are still focused on fiqh only. Secondly on the second status, Ridho Kholid Muhammad also made a narrative status by telling the life of a lecturer in carrying out his duties. Third, the status of Heri Nurdianto is the form of status used is a form of definition exposition. Where he explained the stages that must be passed if someone wants to obtain benefits, they must provide benefits first. Fourth is the status of Rudi Hariyono in the form of an argument and accompanied by an invitation that the reader does not act arrogant because there is nothing that should be boasted by humans and ultimately influence the reader to do what is conveyed in that status. The fifth is Endang Taryono's status although it is displayed in narrative form, by giving an example of a case, but the form of Endang Taryono's status above is a form of persuasion because we find the phrase "let us not quickly get prejudiced" and at the end we also find invitations in the form of "let's always to be kind enough ...

From the data obtained by researchers regarding the meaning of language in Facebook status can be grouped into six different meanings: firstly, denotative variety, almost all Facebook status uses denotative variance, where in this diversity the meanings used are conceptual meanings, original meanings or actual meanings. The second is connotative meaning, in this variety the writer expresses something not with the lexical meaning in this study the writer uses the word "short circuit" to express the meaning of "sick". Third is the idiomatic meaning of various language units that have elements of meaning that cannot be guessed lexically and grammatically. In this research, an example of the word "nano-nano" is taken which means various things. The fourth is the synonym meaning which indicates the relationship of two words that have the same meaning. The fifth is the antonym meaning which indicates the opposite of the meaning of two words. And the sixth is the meaning of ambiguity which indicates the existence of a double meaning.

\section{CONCLUSION}

The difference types or groups of social media allows the emergence of various forms of discourse in writing messages on social media. The different features of social media can give a different impression on every message that is published even though sometimes it has the same form of discourse. Every information published through social media certainly cannot be separated from the meaning contained in it. In this study it was found that the authors of social media messages often use various forms and meanings in expressing opinions and information. The variety of forms that are most easily found on social media is a variety of descriptive form while the variety of meaning is denotative meanings. The denotative meaning is considered appropriate for the writer in describing his/her feelings in original meaning through an article. In addition to the variety of meanings there are also meaning relations. The relations of meaning contained in this study include, the relation of connotative, idiomatic, synonymy, antonymy, and ambiguity.

\section{REFERENCES}

Cecep Dudung Julianto, (2019). Peningkatan Kemampuan Mahasiswa Memahami Struktur Wacana Melalui Metode Analisis Wacana Kritis berbasis Literasi Media social. Dieksis: Jurnal Pendidikan Bahasa dan Sastra Indonesia. Vol 6 no. 1

Chaer, Abdul. (2009). Pengantar Semantik Bahasa Indonesia. Jakarta: Rineka Cipta.

Dewi Arini, Azizah. (2013). Bentuk, Makna, dan Fungsi Bahasa Tulis Media Sosial Sebagai alat Komunikasi dan Interaksi pada Internet. http://journal.unair.ac.id Vol 2 No. 1

Gay, L.R and Mills. (2012). Educational Research. USA: Pearson Education, Inc.

Kholmogorova A.B and Klimenkova E.N. Internet Communication and Emphathy in Adolescence and Early Adulthood.Moscow State University of Psychology and Education(2016). Vol. 8, no. 4, 127141 doi: $10.17759 /$ psyedu.2016080413

Lilimiwirdi, Nelfira. (2016). Pengaruh Internet Dalam Pengembangan Bahasa dan Budaya di Kalangan Remaja Kota Padang. Arbitrer. 2016;3(2):130-151 DOI 10.25077/ar.3.2.130-151.2016

Marwoto, MS; Suyatmi; dan Suyitno. (1987). Komposisi Praktis. Yogyakarta: Hanindita Graha Widya.

Mathers, Dale. (2004). An Introduction to Meaning and Purpose in Analitical Psychology. USA and Canada by Taylor \& Francis Inc

Mukhlishin, Muh Irfan, Maryaeni, Yuni Pratiwi. (2016). Bentuk Gaya Bahasa Komunikasi Facebook Komunitas Seniman Laki-laki. http://journal.um.ac.id Vol 1 No. 6 Hal $1028-1032$

Sobur, Alex. (2004). Analisis Teks Media: Suatu Pengantar untuk Analisis Wacana, Analisis Semiotik, dan Analisis Framing. Bandung: PT. Remaja Rosdakarya

. (2006). Semiotika Komunikasi. Bandung: PT. Remaja Rosdakarya 